\title{
Gambaran Faktor-Faktor yang Berhubungan dengan Kecemasan Pasien Kanker Payudara dalam Menjalani Kemoterapi
}

\author{
Siti Rahmiati Pratiwi ${ }^{1}$, Efri Widianti ${ }^{2}$, Tetti Solehati ${ }^{3}$ \\ ${ }^{1,2,3}$ Fakultas Keperawatan, Universitas Padjadjaran \\ email : ${ }^{1}$ rahmiatipratiwi@gmail.com
}

\begin{abstract}
ABSTRAK
Kanker payudara merupakan penyebab kematian nomor satu dari seluruh jenis kanker yang terjadi pada wanita. Salah satu penanganan kanker payudara adalah dengan menjalani kemoterapi dimana pasien akan mengalami masalah psikologis yaitu kecemasan. Kecemasan yang terjadi dapat dipengaruhi oleh beberapa faktor yaitu ancaman integritas fisik dan ancaman sistem diri. Penelitian ini bertujuan untuk mengetahui gambaran faktor-faktor yang berhubungan dengan kecemasan pasien kanker payudara dalam menjalani kemoterapi di RSUP Dr. Hasan Sadikin Bandung. Jenis penelitian ini adalah deskriptif kuantitatif. Metode pengambilan sampel yang digunakan yaitu accidental sampling, dengan jumlah responden sebanyak 97 orang. Instrumen yang digunakan adalah STAI (State Trait Anxiety Inventory) dan instrumen faktor-faktor yang berhubungan dengan kecemasan dikembangkan dari teori Stuart dan Laraia. Analisis data menggunakan rumus persentase. Hasil penelitian menunjukkan sebagian dari responden mengalami state anxiety sedang $(59,8 \%)$, dan sebagian responden mengalami trait anxiety sedang $(54,6 \%)$. Berdasarkan faktor yang mempengaruhi kecemasan, faktor ancaman sistem diri merupakan faktor yang mendominasi kecemasan pada pasien kanker payudara yang menjalani kemoterapi. Ancaman sistem diri yang mendominasi ini dapat memengaruhi peran dari pasien, sehingga perlu adanya upaya untuk menurunkan kecemasan dengan memperhatikan berbagai faktor yang memengaruhi. Saran bagi perawat dan institusi terkait diharapkan untuk mengkaji lebih lanjut aspek psikososial dan menentukan intervensi selanjutnya untuk mengurangi kecemasan seperti mengajarkan teknik relaksasi, memberi dukungan dan motivasi, serta mendorong pasien untuk melakukan aktivitas fisik.
\end{abstract}

Kata Kunci: Kanker Payudara, Kecemasan, Kemoterapi

\section{ABSTRACT}

Breast cancer is the leading cause of death from all types of cancer that occur in women. On of the treatment of breast cancer is chemotherapy which the patient will experience a psychological problem, such as anxiety. Anxiety can be affected by several factors, there is threat to physical integrity and threat to self-system of patients. The purpose of this research is to determine factors that affect anxiety of breast cancer patients who underwent chemotherapy in RSUP Dr. Hasan Sadikin Bandung. This research used the descriptive quantitative method with 97 participants as a sampling using accidental sampling. STAI (State Trait Anxiety Inventory) and modifying theory of Stuart \& Laraia were used to measure factors that affect anxiety. For analyzing the data, it used percentage abbreviation. The results of this research showed that several of participants experienced moderate state anxiety $(59,8 \%)$, and several participants experienced moderate trait anxiety $(54,6 \%)$. Based on factors that affect anxiety, the factor of the threat to self-system was the factor which dominates anxiety patients with breast cancer who underwent chemotherapy. This domination of self-system threat can affect the role of patients. Therefore it needs some efforts for decreasing anxiety with giving an attention to several factors which affect anxiety. The nurse and institution are expected to assess further aspects of psychosocial and determine next intervention reduce anxiety, such as teaching relaxation techniques, provide support and motivation, and encourage the patient to perform physical activity.

Keywords: Breast Cancer, Anxiety, Chemotherapy 


\section{PENDAHULUAN}

Kanker adalah segolongan penyakit yang ditandai dengan pembelahan sel yang tidak terkendali dan kemampuan sel-sel untuk menyerang jaringan biologis lainnya, baik dengan pertumbuhan langsung di jaringan yang bersebelahan atau dengan migrasi sel ke tempat yang jauh (Amalia, 2009).

Kanker payudara adalah keganasan yang berasal dari sel kelenjar, saluran kelenjar dan jaringan penunjang payudara, tetapi tidak temasuk kulit payudara. Kanker payudara umumnya menyerang wanita yang telah berumur lebih dari 40 tahun, namun wanita muda pun bisa terserang kanker payudara. Kanker payudara merupakan penyakit yang paling ditakuti oleh wanita meskipun kaum pria pun dapat terkena (Purwoastuti, 2008).

Kejadian kanker payudara menempati urutan pertama dan merupakan penyebab kematian wanita terbanyak nomor satu di Indonesia. Berdasarkan estimasi Globocan International Agency Research on Cancer (IARC) tahun 2012, insiden kanker payudara yaitu 40 per 100.000 perempuan.

Pasien yang menderita kanker payudara perlu melakukan terapi pengobatan dalam upaya penyembuhannya. Salah satu pengobatan yang dianjurkan yaitu kemoterapi. Kemoterapi adalah terapi anti kanker untuk membunuh sel-sel tumor dengan menganggu fungsi dan reproduksi sel yang bertujuan untuk penyembuhan, pengontrolan, dan paliatif (Neal, 2006).

Kemoterapi bisa menimbulkan dampak fisiologis maupun psikologis. Dampak fisiologis yang bisa terjadi yaitu rasa lelah, lesu, kerontokan rambut, gangguan usus dan rongga mulut seperti mual muntah, mukositis rongga mulut, gangguan sumsum tulang belakang, kemandulan, gangguan menstruasi \& menopause serta gangguan pada organ lain (Adamsen, L., et.al 2009). Selain menimbulkan dampak fisiologis, kemoterapi juga bisa menimbulkan dampak negatif pada psikologis diantaranya gangguan harga diri, seksualitas, dan kesejahteraan pasien seperti kecemasan (Smeltzer, S. C., et.al, 2008). Berdasarkan penelitian yang dilakukan oleh Oetami, dkk (2014), dampak kanker payudara dan pengobatannya terhadap aspek psikologis menunjukkan bahwa pasien kanker payudara mengekspresikan ketidakberdayaan, kecemasan, rasa malu, harga diri menurun, stres, dan amarah.

Salah satu pertimbangan keperawatan yang harus diperhatikan pada pasien yang menjalani kemoterapi adalah kecemasan (Smeltzer, S. C., et.al, 2008). Berdasarkan hasil penelitian Bintang (2012) menunjukkan bahwa lebih dari $30 \%$ pasien kanker yang menjalani kemoterapi di RSUP Dr. Hasan Sadikin Bandung mengalami cemas sedang dan sisanya mengalami cemas berat hingga depresi.

Kecemasan adalah reaksi emosional yang tidak menyenangkan terhadap bahaya nyata atau imaginer yang disertai dengan perubahan pada sistem saraf otonom dan pengalaman subjektif sebagai "tekanan", "ketakutan", dan "kegelisahan" (Spielberger, C. D, 2010). Kecemasan dibedakan menjadi dua yaitu state anxiety dan trait anxiety. State anxiety adalah gejala kecemasan yang timbul apabila seseorang dihadapkan pada sesuatu yang dianggap mengancam dan bersifat sementara. Trait anxiety adalah kecemasan yang menetap pada diri seseorang yang merupakan pembeda antara satu individu dengan individu lainnya (Spielberger, C. D, 2010).

Menurut Stuart dan Laraia (2009) faktorfaktor yang mempengaruhi kecemasan dibagi menjadi dua yaitu faktor predisposisi dan faktor presipitasi. Faktor predisposisi terdiri dari pandangan psikoanalitik, pandangan interpersonal, pandangan perilaku, kajian keluarga, dan kajian biologis. Faktor presipitasi berasal dari sumber internal dan eksternal yang dapat dikelompokkan menjadi dua kategori yaitu ancaman terhadap 
integritas fisik dan ancaman terhadap sistem diri.

Dampak negatif dari kecemasan bisa terjadi pada pasien kanker payudara. Mohammed S, dkk (2012) menyebutkan bahwa efek kecemasan pada pasien kanker payudara bisa meningkatkan rasa nyeri, mengganggu kemampuan tidur, meningkatkan mual dan muntah setelah kemoterapi, juga terganggunya kualitas hidup diri sendiri. Perasaan cemas yang dirasakan oleh pasien kanker ketika menjalani kemoterapi dapat berdampak buruk pada proses pengobatan serta rehabilitasi secara medis maupun psikologis, seperti yang dikemukakan Bintang (2012) dalam penelitiannya bahwa kecemasan yang terjadi pada pasien kanker yang menjalani kemoterapi bisa mengakibatkan pasien menghentikan kemoterapinya.

Reaksi kecemasan pada seorang pasien kanker sering muncul tidak hanya saat pasien didiagnosa terkena kanker, tetapi juga saat pasien menjalani kemoterapi. Kecemasan ini lazim terjadi karena mengenai masalah finansial, kecemasan saat timbul gejala-gejala yang dirasakan, kekhawatiran mengenai kesembuhan, dan kekhawatiran tidak dapat menjalankan fungsi sebagai perempuan secara maksimal (Tarwoto \& Wartonah, 2004).

\section{METODE}

Penelitian ini dilakukan di Poli Bedah Oncology RSUP Dr. Hasan Sadikin Bandung. Jenis penelitian yang digunakan adalah deskriptif kuantitatif. Variabel dalam penelitian ini adalah tingkat kecemasan dan faktor-faktor yang mempengaruhi kecemasan pasien kanker payudara yang menjalani kemoterapi dan subvariabel penelitian ini adalah ancaman integritas fisik, ancaman sistem diri.

Populasi pada penelitian ini adalah pasien kanker payudara yang menjalani kemoterapi di RSUP Dr. Hasan Sadikin Bandung yang berjumlah pada bulan Maret 2015 yaitu 360 pasien. Teknik pengambilan sampel yang digunakan dalam penelitian ini adalah accidental sampling, sampel dalam penelitian ini sebanyak 97 responden. Teknik pengumpulan data pada penelitian ini adalah dengan menggunakan kuisioner, kuesioner langsung diisi oleh responden dengan adanya pendampingan dari peneliti saat proses pengisian kuesioner.

Analisis data yang digunakan dalam penelitian ini adalah univariat. Untuk mengidentifikasi tingkat kecemasan responden data yang diperoleh dari penjumlahan skor hasil pengisian kuisioner untuk tingkat kecemasan, dimasukkan ke dalam pembagian kategori yaitu ringan, sedang, dan berat. Untuk mengetahui faktorfaktor yang mempengaruhi kecemasan yaitu sebelum dilakukan analisis data, peneliti melakukan uji normalitas terlebih dahulu dan didapatkan hasil distribusi tidak normal sehingga digunakan nilai median. Data yang diperoleh dari penjumlahan skor hasil pengisian kuisioner untuk faktor-faktor yang mempengaruhi kecemasan, dimasukkan ke dalam pembagian kategori yaitu tinggi dan rendah.

\section{HASIL}

Pada penelitian ini didapatkan hasil bahwa sebagian besar dari responden berada pada rentang usia 41-60 tahun yaitu dewasa madya $(62,9 \%)$, pendidikan terakhir sekolah dasar $(44,3 \%)$, frekuensi kemoterapi yang sudah dijalani oleh responden yaitu sebanyak 3 kali (23,7\%), dan sebagian besar responden memiliki penghasilan $<$ UMR Kota Bandung $(61,9 \%)$.

Tabel 1. Distribusi Frekuensi Tingkat State Anxiety dan Tingkat Trait Anxiety Pasien Kanker Payudara yang Menjalani Kemoterapi di RSUP Dr. Hasan Sadikin Bandung Tahun 2015 $(\mathrm{n}=97)$

\begin{tabular}{lcccc}
\hline \multicolumn{1}{c}{ Tingkat } & \multicolumn{2}{c}{ State } & \multicolumn{2}{c}{ Trait } \\
$\begin{array}{l}\text { Kecemasan } \\
\text { Responden }\end{array}$ & F & \% & F & \% \\
\hline Ringan & & & & \\
Sedang & 31 & 32 & 39 & 40,2 \\
\hline
\end{tabular}


\begin{tabular}{lllll}
\hline Berat & 8 & 8,2 & 5 & 5,2 \\
\hline
\end{tabular}

Berdasarkan tabel 1 dapat disimpulkan bahwa tingkat state anxiety pasien kanker payudara yang menjalani kemoterapi sebagian besar mengalami kecemasan sedang yaitu sebanyak 58 responden $(59,8 \%)$. Untuk tingkat trait anxiety pasien kanker payudara yang menjalani kemoterapi sebagian besar mengalami kecemasan sedang yaitu sebanyak 53 responden $(54,6 \%)$.

Tabel 2. Distribusi Frekuensi Faktor yang Mempengaruhi Kecemasan Pasien Kanker Payudara yang Menjalani Kemoterapi di RSUP Dr. Hasan Sadikin Bandung Tahun 2015 (n=97).

\begin{tabular}{lcccc}
\hline \multicolumn{1}{c}{ Faktor yang } & \multicolumn{2}{c}{ Tinggi } & \multicolumn{2}{c}{ Rendah } \\
Mempengaruhi & F & \% & F & \% \\
\hline Ancaman Integritas & 44 & 45,4 & 53 & 54,6 \\
$\begin{array}{l}\text { Fisik } \\
\begin{array}{l}\text { Ancaman Sistem } \\
\text { diri }\end{array}\end{array}$ & 47 & 48,5 & 50 & 51,5 \\
\hline
\end{tabular}

Berdasarkan tabel 2 dapat diketahui bahwa pada faktor integritas fisik hampir setengahnya mempengaruhi kecemasan pasien kanker payudara yang menjalani kemoterapi $(45,4 \%)$, begitu pun untuk faktor sistem diri hampir setengahnya mempengaruhi kecemasan pasien kanker payudara yang menjalani kemoterapi $(48,5 \%)$.

\section{PEMBAHASAN}

Menurut Spielberger, C. D (2010) state anxiety ditandai oleh perasaan subjektif terhadap tekanan, ketakutan, kekhawatiran, dan kecemasan. Kecemasan ini berlangsung sementara dimana kecemasan itu muncul ketika dipicu oleh situasi tertentu yang dihadapi oleh seseorang, dalam hal ini situasi dimana pasien harus menjalani pengobatan kemoterapi yang bisa menimbulkan berbagai macam efek samping pada diri pasien. Tetapi kecemasan sesaat (state anxiety) ini juga sangat dipengaruhi oleh kecemasan bawaan (trait anxiety). Trait anxiety adalah kecemasan yang menetap, merupakan karakteristik individu yang mendasari individu tersebut untuk untuk bersikap terhadap situasi yang berbeda-beda. Seseorang yang memiliki kecemasan bawaan/dasar yang tinggi akan mudah terstimulasi dalam mengalami kecemasan.

Ada beberapa faktor presipitasi yang mempengaruhi timbulnya kecemasan yaitu ancaman integritas fisik dan ancaman sistem diri (Stuart \& Laraia, 2009). Pada penelitian ini didapatkan hasil bahwa ancaman sistem diri merupakan faktor yang lebih dominan dalam mempengaruhi terjadinya kecemasan pada pasien kanker payudara yang menjalani kemoterapi.

Pada penelitian ini sebagian besar responden mengalami perubahan peran dalam keluarganya dan merasa tidak mampu melayani suami dengan maksimal hal ini didapat dari banyaknya responden yang menjawab "sering" pada pernyataan tersebut. Sejalan dengan penelitian yang dilakukan oleh Hartati (2008) bahwa sebagian besar pasien kanker payudara mengalami perubahan peran yang ditandai dengan tidak memiliki kepuasan dalam peran yang dijalankannya yakni pasien merasa tidak mampu melakukan pekerjaan dengan baik sehingga harus dibantu oleh orang lain dan merasa tidak mampu melayani suaminya. Penelitian yang dilakukan oleh Saraswati (2008) juga menunjukkan bahwa terdapat hubungan yang bermakna antara kecemasan pada pasien kanker yang menjalani kemoterapi dengan konsep dirinya.

Menurut Stuart dan Laraia (2009) ancaman sistem diri meliputi ancaman terhadap identitas diri, harga diri, hubungan interpersonal, kehilangan serta perubahan status/peran. Ancaman sistem diri yang bisa menimbulkan kecemasan pada pasien kanker payudara yang menjalani kemoterapi yaitu salah satunya harga diri yang rendah yang dirasakan oleh pasien dikarenakan efek samping kemoterapi yang muncul. Selain itu hal yang dirasakan mungkin adanya perubahan status/peran dalam keluarga, misalnya jika pasien seorang istri dan ibu 
rumah tangga, maka peran sebagai istri dan ibu yang seharusnya mengurus suami dan anak akan terganggu dan tidak akan berfungsi dengan baik.

Faktor lain yang mempengaruhi kecemasan pasien kanker payudara yang menjalani kemoterapi yaitu ancaman integritas fisik. Ancaman integritas fisik menurut Stuart dan Laraia (2009) meliputi ketidakmampuan fisiologis atau penurunan kemampuan untuk memenuhi kebutuhan dasar (penyakit, trauma fisik, pengobatan, atau jenis pembedahan yang akan dilakukan). Pada pasien kaker payudara yang menjalani kemoterapi kecemasan timbul akibat ketidakmampuan atau keterbatasan fisik yang terjadi pada dirinya dikarenakan efek samping yang ditimbulkan kemoterapi. Akibat dari efek samping yang ditimbulkan ini menyebabkan pasien kesulitan untuk memenuhi kebutuhan dasarnya sehingga bisa menimbulkan kecemasan pada pasien. Hal ini sejalan dengan penelitian yang dilakukan oleh Oetami, dkk (2014) bahwa pasien kanker payudara yang menjalani pengobatan mengemukakan kecemasan yang dirasakan yaitu khawatir akan dampak dari pengobatan yang dijalani sehingga tidak dapat melakukan kegiatan sehari-hari seperti sebelumnya. Pada penelitian ini hampir sebagian besar responden merasa khawatir akan efek samping yang timbul dari kemoterapi yang dapat mengganggu aktifitas sehari-hari mereka. Sejalan dengan penelitian Nurpeni (2013) bahwa perasaan cemas yang dirasakan oleh pasien yang menjalani pengobatan diakibatkan oleh penurunan fungsi fisik yang berpengaruh pada aktifitas sehari-harinya.

Berdasarkan hasil penelitian didapatkan bahwa pasien kanker payudara yang menjalani kemoterapi hampir sebagian besar $(62,9 \%)$ berada pada usia antara 41-60 tahun yaitu dewasa madya. Menurut Harlock (2009) bahwa masa dewasa madya merupakan masa transisi dan masa penyesuaian kembali dengan pola perilaku yang telah dilakukan di masa dewasa awal dengan perubahan fisik dan mental yang terjadi di usia madya. Hal ini sejalan dengan penelitian Wardhani (2012) bahwa lebih sekitar 68,5\% pasien kanker payudara yang mengalami kecemasan berada dalam rentang usia 40-60 tahun.

Dilihat dari karakteristik lain yaitu pendidikan, hampir sebagian dari responden (44,3\%) berpendidikan terakhir sekolah dasar, sejalan dengan penelitian Yunitasari (2012) bahwa tingkat pendidikan berpengaruh pada tingkat kecemasan seseorang yakni semakin tinggi tingkat pendidikan seseorang semakin rendah pula kemungkinan mengalami kecemasan, dan sejalan juga dengan penelitian Kuraesin (2009) bahwa tingkat pendidikan bisa mempengaruhi seseorang dalam mengidentifikasi stressor dalam diri sendiri maupun dari luarnya, tingkat pendidikan juga mempengaruhi kesadaran dan pemahaman terhadap stimulus, kondisi ini menunjukkan bahwa respon cemas berat cenderung terjadi pada pasien yang berpendidikan rendah. Hampir sebagian dari responden $(61,9 \%)$ memiliki penghasilan kurang dari UMR Kota Bandung, hal ini sejalan dengan penelitian Hartati (2008) bahwa status ekonomi yang rendah dapat menambah rasa cemas pada pasien kanker payudara. Selain itu hal ini sejalan juga dengan teori Stuart dan Sundeen (1998) yang menyatakan bahwa status ekonomi yang rendah pada seseorang akan menyebabkan orang tersebut mudah mengalami kecemasan.

Dilihat dari hasil penelitian, kecemasan yang terjadi pada pasien hampir sebagian besar responden mengalami kecemasan sedang baik pada state anxiety maupun trait anxiety. Menurut Stuart (2013) kecemasan sedang memungkinkan individu berfokus pada hal yang penting dan mengesampingkan yang lain. Kecemasan ini mempersempit lapang persepsi individu tetapi individu masih bisa melakukan sesuatu dengan arahan orang lain. Selain itu apabila kecemasan ini tidak segera diatasi maka akan berdampak pada kemoterapi yang dijalani oleh pasien, seperti menurut penelitian Bintang 
dikemukakan bahwa kecemasan yang terjadi pada pasien kanker yang menjalani kemoterapi bisa mengakibatkan pasien menghentikan kemoterapinya. Mohammed, dkk (2012) mengemukakan dalam penelitiannya bahwa dampak kecemasan pada pasien kanker payudara yaitu dapat meningkatkan rasa sakit, mual muntah, kesulitan tidur hingga terganggunya kualitas hidup. Kecemasan yang terjadi juga dapat menurunkan daya tahan tubuh akibat meningkatnya kortisol yang dapat menyebabkan berkurangnya sel darah putih (Taylor, S.E, 2012).

Oleh karena itu, disinilah peran perawat sangat dibutuhkan untuk mengatasi kecemasan yang dialami pasien agar kecemasan pasien tidak naik ke tingkat yang lebih tinggi. Asuhan keperawatan yang diberikan tidak hanya menyangkut kebutuhan dasar tetapi juga kondisi psikologis yang dialami oleh pasien. Intervensi yang diberikan dapat dilihat dari berat ringannya state dan trait anxiety seseorang. Jika state anxiety sedang, trait anxiety sedang maka dapat diberikan intervensi seperti pengkajian kondisi psikologis, memberikan dukungan dan motivasi, menjadi pendengar yang baik, mengembangkan pola mekanisme koping yang positif dengan tujuan pasien akan menunjukkan cara koping adaftif terhadap stress sehingga kecemasan pasien dapat menurun pada tingkat kecemasan ringan. Berdasarkan hasil penelitian Rollintan (2006) untuk mengatasi kecemasan yang dialami oleh pasien kanker payudara paling banyak menggunakan strategi koping yang berorientasi pada ego yaitu: berdo'a dan berharap. Tetapi jika state anxiety berat, trait anxiety juga berat tentu saja diperlukan intervensi yang lebih spesifik dan strategi khusus dalam pemberian asuhan keperawatan.

\section{SIMPULAN}

Berdasarkan penelitian dan pengolahan data yang telah dilakukan mengenai gambaran faktor-faktor yang mempengaruhi kecemasan pasien kanker payudara yang menjalani kemoterapi di RSUP Dr. Hasan Sadikin Bandung yang berjumlah 97 orang responden, disimpulkan bahwa pada tingkat kecemasan State hampir sebagian besar responden mengalami kecemasan sedang, begitu pula pada tingkat kecemasan Trait hampir sebagian dari responden mengalami kecemasan sedang. Kemudian untuk faktor yang mempengaruhi kecemasan pasien kanker payudara yang menjalani kemoterapi hampir sebagian dari responden yang mengalami kecemasan dipengaruhi oleh faktor ancaman sistem diri dan sebagian dipengaruhi oleh faktor ancaman integritas fisik.

\section{SARAN}

Penelitian ini, diharapkan hasil penelitian dapat memberikan informasi bagi RSUP Dr. Hasan Sadikin Bandung, khususnya kepada perawat di institusi terkait mengenai adanya tingkat kecemasan dan faktor yang mempengaruhi kecemasan pada pasien kanker payudara yang menjalani kemoterapi sehingga perawat dapat mengkaji lebih lanjut dan menentukan intervensi selanjutnya sesuai dengan tingkat kecemasan dan faktor yang mempengaruhinya. Meskipun hasil penelitian menyatakan bahwa hampir sebagian besar responden berada pada tingkat kecemasan sedang, tetapi apabila tidak ditangani kemungkinan kecemasannya bisa menjadi ke tingkat lebih tinggi. Intervensi yang diberikan dapat berupa pengkajian lebih lanjut mengenai kondisi psikologis pasien, memberikan dukungan dan motivasi, menjadi pendengar yang baik, mendorong pasien untuk menggunakan koping yang efektif, menganjurkan pasien untuk melakukan aktifitas fisik dan mengajarkan teknik relaksasi untuk mengurangi kecemasan pasien.

Hasil dari penelitian ini memberikan gambaran tentang faktor yang mempengaruhi kecemasan pasien kanker payudara yang menjalani kemoterapi sehingga dapat 
dijadikan data dasar untuk penelitian selanjutnya mengenai hubungan faktor ancaman sistem diri/faktor ancaman integritas fisik dengan kecemasan pasien kanker payudara yang menjalani kemoterapi.

\section{DAFTAR PUSTAKA}

Adamsen, L., Quist, M., Andersen, C., Møller, T., Herrstedt, J., Kronborg, D., ... \& Stage, M. (2009). Effect of a multimodal high intensity exercise intervention in cancer patients undergoing chemotherapy: randomised controlled trial. Bmj, 339, b3410.

Amalia. (2009). Mengobati Kanker Serviks dan 33 Jenis Kanker Lainnya. Jogjakarta: Landscape.

Bintang, Y. A. (2012). Gambaran Tongkat Kecemasan, Stress, dan Depresi Pada Pasien Kanker yang Menjalani Kemoterapi Di RSUP Dr. Hasan Sadikin Bandung. Students e-Journal Unpad.

Harlock, E. B. (2009). Psikologi Perkembangan Edisi Kelima. Jakarta: Erlangga.

Hartati, A. S. (2008). Konsep Diri dan Kecemasan Wanita Kanker Payudara Di Poli Bedah Onkologi Rumah Sakit Umum Pusat Haji Adam Malik Medan. Universitas Sumatera Utara.

Kuraesin, N. D. (2009). Faktor-Faktor yang Mempengaruhi Tingkat Kecemasan Pasien yang Akan Mengahadapi Operasi Di RSUP Fatnawati. Universitas Islam Negri Syarif Hidayatulloh.

Mohamed, S., \& Baqutayan, S. (2012). The Effect of Anxiety on Breast Cancer. Indian Journal of Psychological Medicine Vol 34.

Neal, M. J. (2006). Farmakologi Medis Edisi Kelima. Jakarta: Erlangga.

Nurpeni, R. K. (2013). Hubungan Dukungan Keluarga dengan Tingkat Kecemasan
Pada Pasien Kanker Payudara (Ca Mammae) di Ruang Angsoka III RSUP Sanglah Denpasar. Universitas Udayana.

Oetami, F., M. Thaha, I. L., \& Wahiduddin. (2014). Analisis Dampak Psikologis Pengobatan Kanker Payudara Di RS Dr. Wahidin Sudirohusodo Kota Makassar. Universitas Hasanuddin.

Purwoastuti, E. (2008). Kanker Payudara. Yogyakarta: Kanisius.

Rollintan, E.M. (2006). Hubungan Antara Ansietas dengan Koping pada Pasien Kanker di Rumah Sakit Umum Pusat Haji Adam Malik Medan. Universitas Sumatera Utara.

Saraswati, S. H. (2008). Hubungan Antara Kecemasan Pada Penderita Kanker yang Mendapat Kemoterapi dengan Konsep Diri. Universitas Diponegoro.

Smeltzer, S. C., Bare, B. G., Hinkle, J. L., Cheever, K. H., Townsend, M. C., \& Gould, B. (2008). Brunner and Suddarth's textbook of medicalsurgical nursing 10th edition. Philadelphia: Lipincott Williams \& Wilkins.

Spielberger, C. D. (2010). State-Trait anxiety inventory. John Wiley \& Sons, Inc..

Stuart, G. W. (2013). Buku Saku Keperawatan Jiwa Edisi Kelima. Jakarta: EGC.

Stuart, G. W., \& Laraia, M. T. (2009). Principle and Practice of Psychiatric Nursing. Envolve.

Tarwoto \& Wartonah. (2004). Kebutuhan Dasar Manusia dan Proses Keperawatan. Jakarta: Salemba Medika.

Taylor, S.E. (2012). Health Psychology. New York: McGrew Hill.

Wardhani, D.I. (2012). Gambaran Tingkat Kecemasan Pada Pasien Kanker Payudara yang Menjalani Kemoterapi di RSUD Al-Ihsan Kab. Bandung yang Telah Menerapkan Spiritual Care. Bandung: Universitas Padjadjaran. 
Pratiwi, S.R., Widianti, E., Solehati, T.

Yunitasari, L. N. (2012). Hubungan Beberapa Faktor Demografi dengan Tingkat Kecemasan Pasien Pasca Diagnosis
Kanker di RSUP Dr. Kariadi Semarang. Medica Hospitalia Vol 1, 127-129. 